\title{
Diagnosis and Treatment of Growth Hormone Deficiency: A Position Statement from Korean Endocrine Society and Korean Society of Pediatric Endocrinology
}

\author{
Jung Hee Kim ${ }^{1}$, Hyun Wook Chae ${ }^{2}$, Sang Ouk Chin ${ }^{3}$, Cheol Ryong $\mathrm{Ku}^{4}$, Kyeong Hye Park ${ }^{5}$, Dong Jun Lim 6 , \\ Kwang Joon Kim ${ }^{7}$, Jung Soo Lim ${ }^{8}$, Gyuri Kim ${ }^{9}$, Yun Mi Choi ${ }^{10}$, Seong Hee Ahn ${ }^{11}$, Min Ji Jeon ${ }^{12}$, Yul Hwangbo ${ }^{13}$, \\ Ju Hee Lee ${ }^{14}$, Bu Kyung Kim ${ }^{15}$, Yong Jun Choi ${ }^{16}$, Kyung Ae Lee ${ }^{17}$, Seong-Su Moon ${ }^{18}$, Hwa Young Ahn ${ }^{19}$, \\ Hoon Sung Choi ${ }^{20}$, Sang Mo Hong ${ }^{10}$, Dong Yeob Shin ${ }^{4}$, Ji A Seo ${ }^{21}$, Se Hwa Kim ${ }^{22}$, Seungjoon $\mathrm{Oh}^{3}$, Sung Hoon $\mathrm{Yu}^{23}$, \\ Byung Joon $\mathrm{Kim}^{24}$, Choong Ho Shin ${ }^{25}$, Sung-Woon Kim³ ${ }^{3}$, Chong Hwa Kim ${ }^{26}$, Eun Jig Lee ${ }^{4}$
}

${ }^{1}$ Department of Internal Medicine, Seoul National University Hospital, Seoul National University College of Medicine; ${ }^{2}$ Department of Pediatrics, Yonsei University College of Medicine; ${ }^{3}$ Department of Endocrinology and Metabolism, Kyung Hee University School of Medicine; ${ }^{4}$ Division of Endocrinology and Metabolism, Department of Internal Medicine, Yonsei University College of Medicine, Seoul; ${ }^{5}$ Division of Endocrinology and Metabolism, Department of Internal Medicine, National Health Insurance Service Ilsan Hospital, Goyang; ${ }^{6}$ Division of Endocrinology and Metabolism, Department of Internal Medicine, College of Medicine, The Catholic University of Korea; ${ }^{7}$ Division of Geriatrics, Department of Internal Medicine, Yonsei University College of Medicine, Seoul; ${ }^{8}$ Department of Internal Medicine, Yonsei University Wonju College of Medicine, Wonju; ${ }^{9}$ Division of Endocrinology and Metabolism, Department of Medicine, Thyroid Center, Samsung Medical Center, Sungkyunkwan University School of Medicine, Seoul; ${ }^{10}$ Department of Internal Medicine, Hallym University Dongtan Sacred Heart Hospital, Hallym University College of Medicine, Hwaseong; ${ }^{11}$ Department of Endocrinology, Inha University School of Medicine, Incheon; ${ }^{12}$ Department of Internal Medicine, Asan Medical Center, University of Ulsan College of Medicine, Seoul; ${ }^{13}$ Department of Internal Medicine, National Cancer Center, Goyang; ${ }^{14}$ Department of Internal Medicine, Chungnam National University College of Medicine, Daejeon; ${ }^{15}$ Department of Internal Medicine, Kosin University College of Medicine, Busan; ${ }^{16}$ Department of Endocrinology and Metabolism, Ajou University School of Medicine, Suwon; ${ }^{17}$ Division of Endocrinology and Metabolism, Department of Internal Medicine, Research Institute of Clinical Medicine of Jeonbuk National University-Biomedical Research Institute of Jeonbuk National University Hospital, Jeonju, ${ }^{18}$ Department of Internal Medicine, Dongguk University College of Medicine, Gyeongju; ${ }^{19}$ Department of Internal Medicine, Chung-Ang University College of Medicine, Seoul; ${ }^{20}$ Department of Internal Medicine, Kangwon National University School of Medicine, Chuncheon; ${ }^{21}$ Division of Endocrinology, Department of Internal Medicine, Korea University Ansan Hospital, Korea University College of Medicine, Ansan; ${ }^{22}$ Department of Internal Medicine, International St. Mary's Hospital, Catholic Kwandong University College of Medicine, Incheon; ${ }^{23}$ Department of Endocrinology and Metabolism, Hanyang University Guri Hospital, Hanyang University College of Medicine, Guri; ${ }^{24}$ Division of Endocrinology, Department of Internal Medicine, Gachon University College of Medicine, Incheon; ${ }^{25}$ Department of Pediatrics, Seoul National University College of Medicine, Seoul; ${ }^{26}$ Division of Endocrinology and Metabolism, Department of Internal Medicine, Sejong General Hospital, Bucheon, Korea

Received: 4 February 2020, Revised: 2 April 2020, Accepted: 23 April 2020 Corresponding authors: Chong Hwa Kim

Division of Endocrinology and Metabolism, Department of Internal Medicine, Sejong General Hospital, 28 Hohyeon-ro 489beon-gil, Sosa-gu, Bucheon 14754, Korea Tel: +82-32-340-1116, Fax: +82-32-340-1236, E-mail: drangel@sejongh.co.kr Eun Jig Lee Division of Endocrinology and Metabolism, Department of Internal Medicine, Yonsei University College of Medicine, 50-1 Yonsei-ro, Seodaemun-gu, Seoul 03722, Korea

Tel: +82-2-2228-1983, Fax: +82-2-393-6884, E-mail: ejlee423@yuhs.ac

\section{Copyright $\odot 2020$ Korean Endocrine Society}

This is an Open Access article distributed under the terms of the Creative Commons Attribution Non-Commercial License (https://creativecommons.org/ licenses/by-nc/4.0/) which permits unrestricted non-commercial use, distribution, and reproduction in any medium, provided the original work is properly cited. 
Growth hormone (GH) deficiency is caused by congenital or acquired causes and occurs in childhood or adulthood. GH replacement therapy brings benefits to body composition, exercise capacity, skeletal health, cardiovascular outcomes, and quality of life. Before initiating GH replacement, GH deficiency should be confirmed through proper stimulation tests, and in cases with proven genetic causes or structural lesions, repeated GH stimulation testing is not necessary. The dosing regimen of GH replacement therapy should be individualized, with the goal of minimizing side effects and maximizing clinical improvements. The Korean Endocrine Society and the Korean Society of Pediatric Endocrinology have developed a position statement on the diagnosis and treatment of GH deficiency. This position statement is based on a systematic review of evidence and expert opinions.

Keywords: Growth hormone; Dwarfism, pituitary; Hypopituitarism; Hormone replacement therapy

\section{SUMMARY}

\section{Diagnosis of growth hormone deficiency in adults}

1. The insulin tolerance test is recommended as the standard test for diagnosing growth hormone $(\mathrm{GH})$ deficiency (B).

2. When GH deficiency is suspected, but an insulin tolerance test is contraindicated, two or more GH stimulation tests (GH-releasing hormone-arginine, glucagon, levodopa, or clonidine stimulation tests) should be administered (B).

3. GH deficiency cannot be ruled out even if insulin-like growth factor-1 (IGF-1) levels are normal. However, low serum IGF-1 levels may be indicative of GH deficiency in individuals who do not have a history of poorly controlled diabetes, chronic liver disease, or treatment with oral contraceptives (C).

4. GH deficiency can be diagnosed without GH stimulation testing when the typical clinical characteristics of GH deficiency are present, accompanied by deficiencies in three or more pituitary hormones with low serum IGF-1 levels (B).

5. Repeated GH stimulation testing should be performed in patients with childhood-onset GH deficiency if they do not have a proven genetic cause of GH deficiency or irreversible damage (B).

6. Adult patients with irreversible pituitary damage should not receive repeated GH stimulation tests (B).

\section{Treatment of growth hormone deficiency in adults}

1. Unless contraindicated, GH therapy is recommended for patients with GH deficiency. GH therapy should start from a low dose, considering the patient's age, sex, and estrogen levels (A).

2. Clinical improvements, side effects, and targeting serum IGF-1 levels within the age-adjusted reference range should be considered when adjusting the GH dose (A).

3. During the adjustment period, IGF-1 levels should be monitored monthly or bimonthly. Once the maintenance level is determined, IGF-1 levels should be monitored around twice per year. Monitoring should include an evaluation of the patient's clinical response, side effects, and IGF-1 levels (B).

\section{Diagnosis and treatment of growth hormone deficien- cy in children and adolescents}

1. Two or more GH stimulation tests should be administered when GH deficiency is suspected in children (A).

2. Repeated GH stimulation tests are not required in $\mathrm{GH}$ patients with pituitary lesions or a proven genetic cause of GH deficiency (C).

3. GH replacement should be continued in children and adolescents until the epiphyseal plates close or their full height is reached (C).

4. GH replacement should be resumed as soon as possible in patients with $\mathrm{GH}$ deficiency during transition (B).

\section{Benefits of growth hormone treatment}

1. GH treatment improves body composition, exercise capacity, and bone mineral density in patients with GH deficiency (A).

2. GH treatment lowers the risk of cardiovascular disease in patients with GH deficiency, but there is insufficient evidence regarding its effects on mortality reduction (B). 
3. GH treatment improves quality of life in patients with GH deficiency (A).

\section{Risks and side effects of growth hormone treatment}

1. GH treatment is contraindicated in patients with an active malignancy (except basal cell or squamous cell skin cancers) (A).
2. Changes in blood glucose levels should be observed during the course of GH treatment in patients with diabetes mellitus, who may require their antidiabetic medication to be adjusted (B).

3. Thyroid and adrenal gland function should be monitored during $\mathrm{GH}$ treatment in patients with hypopituitarism (B).

\section{INTRODUCTION}

Growth hormone (GH) deficiency can be categorized into childhood-onset and adult-onset. Childhood-onset GH deficiency can be further categorized as congenital, acquired, or idiopathic. Adult-onset GH deficiency is generally acquired, although GH deficiency in adults can also occur as a continuation of childhood-onset GH deficiency. The congenital causes are mutations of genes related to $\mathrm{GH}$ synthesis and $\mathrm{GH}$ receptors and developmental structural disabilities in the brain. The main causes of acquired GH deficiency are tumors in the pituitary gland and hypothalamus, the treatment of such tumors with surgery or radiation, infiltrative diseases, vascular damage, and infections (Table 1) [1,2].

The most common cause of adult-onset GH deficiency is hypothalamic-pituitary tumors - either the tumor itself, or surgery

Table 1. Cause of Growth Hormone Deficiency

\begin{tabular}{|c|c|}
\hline Congenital & Acquired \\
\hline Genetic & Neoplastic \\
\hline Transcription factor defects (PIT-1, PROP-1, LHX3/4, HESX-1, PITX-2) & Pituitary adenoma \\
\hline GHRH receptor gene defects & Craniopharyngioma \\
\hline GH secretagogue receptor gene defects & Rathke's cleft cyst \\
\hline GH gene defects & Glioma/astrocytoma \\
\hline GH receptor/post receptor defects & Germinoma \\
\hline Associated with brain structural defects & Metastatic \\
\hline Agenesis of corpus callosum & Infiltrative/granulomatous disease \\
\hline Septo-optic dysplasia & Langerhans cell histiocytosis \\
\hline Empty sella syndrome & Sarcoidosis \\
\hline Holoprosencephaly & Hypophysitis \\
\hline Encephalocele & Vascular damage \\
\hline Hydrocephalus & Head injury \\
\hline Arachnoid cyst & Pituitary tumor apoplexy \\
\hline Associated with midline facial defects & Sheehan's syndrome \\
\hline Single central incisor & Subarachnoid hemorrhage \\
\hline \multirow[t]{5}{*}{ Cleft lip/palate } & Treatment of pituitary and hypothalamic diseases \\
\hline & Cranial irradiation \\
\hline & Surgery of the pituitary or hypothalamus \\
\hline & Central nervous system infection \\
\hline & Idiopathic \\
\hline
\end{tabular}

Modified from Molitch et al. [1]; and Melmed [2], with permission from Massachusetts Medical Society.

PIT-1, pituitary transcription factor-1; PROP-1, prophet of pit-1; LHX3/4, LIM class homeobox transcription factor Lhx3, 4; HESX-1, homeobox-1; PITX-2, paired-like homeodomain transcription factor-2; GHRH, growth hormone-releasing hormone; GH, growth hormone. 
or radiation treatment performed to treat the tumor. Although it is rare for pituitary microadenoma to present with hypopituitarism, pituitary macroadenoma presents with at least one pituitary hormone deficiency in approximately $30 \%$ to $60 \%$ of cases [3]. The main mechanism of hormone deficiency is disruption of circulation due to pressure on the portal veins of the pituitary stalk [4]. Hypopituitarism can also occur after the removal of pituitary tumors, but surgery can lead to a $50 \%$ recovery of tumor-induced hypopituitarism [5]. However, GH is the least recovering pituitary hormone [4]. Radiation also induces GH deficiency. The risk of GH deficiency after intracranial radiation is higher in younger patients, and increases with the time after radiation therapy [6]. If the amount of radiation is above $40 \mathrm{~Gy}$, there is a $50 \%$ chance of GH deficiency [7].

GH deficiency occurs in $25 \%$ of patients with head injury or subarachnoid hemorrhage $[8,9]$. Some patients recover with time, while others deteriorate; therefore, pituitary hormone levels in these patients should be monitored upon admission and at regular intervals thereafter.

Clinically, patients with GH deficiency report increased body fat, decreased muscle mass, lethargy, and decreased quality of life [10]. However, the presenting symptoms such as fatigue and weakness are nonspecific and common. Therefore, controversy has persisted regarding the correct diagnosis and appropriate treatment of GH deficiency. The Insurance Committee of the Korean Endocrine Society therefore developed a guideline for the diagnosis and treatment of GH deficiency, as cases of GH deficiency increase and some issues arise regarding insurance reimbursements in South Korea.

\section{METHODS USED IN THE DEVELOPMENT OF THIS GUIDELINE}

This guideline was developed by the Insurance Committee of the Korean Endocrine Society in consultation with the Korean Neuroendocrine Study Group, and the Korean Society of Pediatric Endocrinology. Since there are currently no diagnostic guidelines for GH deficiency and few domestic research has been conducted on this topic, the basis of this guideline was formed by consensus from panel discussion of experts, and the review of existing literature. When evidence was insufficient, recommendations were written according to experts' opinions. When there were differences in opinions, a majority vote was taken. Each recommendation was graded according to the strength of evidence supporting the recommendation, as defined in Table 2.

\section{DISCUSSION OF THE RECOMMENDATIONS}

\section{Diagnosis of growth hormone deficiency in adults}

GH deficiency is suspected in patients with suggestive clinical presentations (increased body fat, decreased muscle mass, lethargy, and decreased quality of life), and it is diagnosed through GH stimulation tests. An evaluation for GH deficiency should be considered in patients with conditions that can cause GH deficiency, since GH deficiency can be misdiagnosed in patients who only have non-specific clinical symptoms such as lethargy, weakness, and obesity. Before GH secretion is tested, other deficient hormones should be supplemented. Since GH is released in spurts, GH deficiency is diagnosed through GH stimulation

Table 2. Definition of Recommendation Levels

Recommendation

level

Definition

A When there is a clear rationale for the recommendations:

When manifold randomized controlled trials that can be generalized because they have sufficient test or meta-analysis results support a recommendation.

B When there is a reliable basis for the recommendations:

When reasonable grounds support this through well-performed cohort studies or patient—control group studies.

C When there is a possible basis for the recommendations:

When relevant grounds are seen through randomized clinical studies or case reports and observational studies carried out in a small institution, despite their inherent unreliability.

$\mathrm{E}$

Expert recommendations:

There is no basis to support the recommendations, but they are supported by expert opinion or expert clinical experience. 
tests such as the insulin tolerance test (ITT), the growth hormone-releasing hormone (GHRH), arginine, glucagon, levodopa, and clonidine stimulation tests. There is no single gold-standard test, but the ITT is a major GH stimulation test. The use of GHRH is withdrawn in South Korea as well as in the United States. The basic principle of GH stimulation test is consecutively measuring blood GH levels after an administration of a medication that rapidly stimulates GH. The highest GH level in the samples is then interpreted as the patient's GH response. Table 3 summarizes the methods, standards, and precautions for GH stimulation tests.

\subsection{The insulin tolerance test is recommended as the standard test for diagnosing $\mathbf{G H}$ deficiency.}

1.2. When GH deficiency is suspected, but an ITT is contraindicated, two or more GH stimulation tests (GHRHarginine, glucagon, levodopa, or clonidine stimulation tests) should be administered.

The ITT is recommended as the standard test for the diagnosis of GH deficiency. ITT has been validated as a standard test for GH deficiency, but it causes hypoglycemia; therefore, it is contraindicated in elderly patients and patients with a history of epilepsy or cardiovascular disease due to its risks [11]. Even healthy individuals should be continuously monitored during ITT. In obese patients with insulin resistance, a greater dose of insulin is injected to induce hypoglycemia, and this process increases the risk of delayed hypoglycemia. ITT is also difficult to replicate, since the response to ITT varies from occasion to occasion in healthy individuals. The response to ITT also depends on the menstrual cycle.

Aimaretti et al. [12] reported that injecting arginine, which suppresses the secretion of hypothalamic somatostatin, together with GHRH served as a potent and safe GH stimulation test. Biller et al. [13] compared five types of GH stimulation tests. In their study, five stimulation tests were administered in random order to 39 patients with panhypopituitarism, 21 patients with either isolated $\mathrm{GH}$ deficiency or no more than one additional pituitary hormone deficiency, and 34 healthy controls matched by age, sex, and body mass index (BMI). At a GH level of $5.1 \mu \mathrm{g} / \mathrm{L}$, ITT had 96\% sensitivity and 92\% specificity, and the GHRHarginine test had a similar diagnostic validity at a GH level of

Table 3. Dynamic Tests for Diagnosing GH deficiency

\begin{tabular}{|c|c|c|c|}
\hline Hormone test & Procedure & GH cut-points, $\mu \mathrm{g} / \mathrm{L}$ & Consideration \\
\hline ITT & $\begin{array}{l}\text { Administer insulin, } 0.05-0.15 \mathrm{U} / \mathrm{kg} \text { iv } \\
\text { Sample blood at }-30,0,30,60,120 \mathrm{~min} \text { for } \mathrm{GH} \text { and } \\
\text { glucose }\end{array}$ & $\begin{array}{l}>5.0(\mathrm{AACE}, 2019) \\
>3-5(\mathrm{ES}, 2016)\end{array}$ & $\begin{array}{l}\text { Glucose should drop }<40 \mathrm{mg} / \mathrm{dL} \\
\text { Contraindication: a history of seizures, coronary artery } \\
\text { disease, pregnancy, or age }>65 \mathrm{yr}\end{array}$ \\
\hline GHRH-arginine & $\begin{array}{l}\text { Administer GHRH, } 1 \mu \mathrm{g} / \mathrm{kg}(\max 100 \mu \mathrm{g} \text { ) iv } \\
\text { followed by an arginine infusion } 0.5 \mathrm{~g} / \mathrm{kg} \\
\text { (max } 35 \mathrm{~g} \text { ) over } 30 \mathrm{~min} \\
\text { Sample blood at } 0,30,45,60,75,90,105 \text {, and } \\
120 \text { min for } \mathrm{GH}\end{array}$ & $\begin{array}{c}>4 \mu \mathrm{g} / \mathrm{L} \text { but cutoffs for } \\
\text { GH response should } \\
\text { be correlated to BMI }\end{array}$ & $\begin{array}{l}\text { Can give false normal GH response if GHD is due to } \\
\text { hypothalamic damage }\end{array}$ \\
\hline Glucagon & $\begin{array}{l}\text { Administer glucagon, } 1 \mathrm{mg}(1.5 \mathrm{mg} \text { if weight } \\
>90 \mathrm{~kg}) \mathrm{im} \\
\text { Sample blood at } 0,30,60,90,120,150,180,210 \text {, } \\
\text { and } 240 \mathrm{~min} \text { for } \mathrm{GH} \text { and glucose }\end{array}$ & $\begin{array}{l}>3 \mu \mathrm{g} / \mathrm{L}(\text { if BMI } \\
\left.\quad \geq 25 \mathrm{~kg} / \mathrm{m}^{2},>1 \mu \mathrm{g} / \mathrm{L}\right)\end{array}$ & $\begin{array}{l}\text { Obesity may blunt GH response to stimulation } \\
\text { Contraindication: severe fasting hyperglycemia } \\
>180 \mathrm{mg} / \mathrm{dL} \\
\text { Nausea, vomiting, headache, and delayed hypoglyce- } \\
\text { mia may occur }\end{array}$ \\
\hline Levodopa & $\begin{array}{l}\text { Administer Levodopa } 500 \mathrm{mg} \text { po } \\
\text { Sample blood at } 0,60,90 \text {, and } 120 \mathrm{~min} \text { for } \mathrm{GH}\end{array}$ & $>3 \mu \mathrm{g} / \mathrm{L}$ & Nausea, vomiting, dizziness, and headache may occur \\
\hline Clonidine & $\begin{array}{l}\text { Administer clonidine, } 0.15 \mathrm{mg} / \mathrm{m}^{2}(\max 0.25 \mathrm{mg}) \text { po } \\
\text { Sample blood at } 0,30,60,90 \text {, and } 120 \mathrm{~min} \text { for } \mathrm{GH}\end{array}$ & $>3 \mu \mathrm{g} / \mathrm{L}$ & $\begin{array}{l}\text { Hypotension and drowsiness may occur } \\
\text { Contraindication: a history of coronary artery disease }\end{array}$ \\
\hline Macimorelin & Administer $0.5 \mathrm{mg} / \mathrm{kg}$, oral solution & $>2.8 \mu \mathrm{g} / \mathrm{L}$ & $\begin{array}{l}\text { Avoid concomitant use with drugs known to prolong } \\
\text { QT interval; hypothalamic disease may not be accu- } \\
\text { rately diagnosed side effect: mild dysgeusia }\end{array}$ \\
\hline
\end{tabular}

GH, growth hormone; ITT, insulin-tolerance test; iv, intravenous; AACE, American Association of Clinical Endocrinologists; ES, Endocrine Society; GHRH, growth hormone-releasing hormone; BMI, body mass index; GHD, growth hormone deficiency; im, intramuscular; po, per os. 
$4.1 \mu \mathrm{g} / \mathrm{L}$, with $95 \%$ sensitivity and $91 \%$ specificity. GHRH, however, stimulates the pituitary gland directly and may result in false negatives in patients with disorders in the hypothalamus or a history of radiation treatment. The GH level for the GHRHarginine test needs to be adjusted in patients who are older or have a higher BMI $[14,15]$. A higher BMI also leads to a slightly lower GH response in ITT, but it is not recommended to adjust the GH levels for the diagnostic cut-point [16]. For tests using arginine alone, a GH level of $0.4 \mu \mathrm{g} / \mathrm{L}$ was identified as a suitable cut-point; however, this low value compromises diagnostic accuracy, and this test is therefore not recommended.

Glucagon indirectly stimulates GH by stimulating insulin secretion; since the GH response is delayed, the glucagon stimulation test requires a minimum of 3 hours to complete and poses a risk of delayed hypoglycemia. For this test, intramuscular or subcutaneous injection is more effective than intravenous injection. The GH level for diagnosis is adequate at $3 \mu \mathrm{g} / \mathrm{L}$, while in patients with obesity (BMI $>25 \mathrm{~kg} / \mathrm{m}^{2}$ ) whose GH response is less sensitive, the GH level for diagnosis is $1 \mu \mathrm{g} / \mathrm{L}$ [17-21]. Although higher blood glucose levels are associated with a weaker GH response, specific GH levels for diagnosis according to blood glucose levels have not been determined yet [22]. Side effects include nausea, vomiting, and headaches; furthermore, severe hypotension, hypoglycemia, and convulsions have been reported in the elderly.

Levodopa stimulates GH through dopamine receptors in the hypothalamus, and clonidine through releasing GHRH via alpha receptors. Levodopa and clonidine are weak GH stimulators, so a diagnosis is possible when a sensitive method of GH measurement is used. There are lack of data regarding the optimal GH cut-off values according to age, sex, BMI, blood glucose levels, or the presence of any underlying disorders.

Macimorelin, an oral GH secretagogue receptor-1a agonist that was recently approved in the United States and Europe, stimulates GH release with similar sensitivity (92\%) and specificity $(96 \%)$ to ITT, and has fewer side effects [23]. A common side effect is a slight disturbance in taste that improves with time, although a severe side effect reported was long QT interval on electrocardiography. Macimorelin is not yet introduced in South Korea.

The analytical method of determining GH levels has a major impact on the GH cut-off value for the diagnosis of GH deficiency. Thus, it is important to ensure that accurate measurements of GH are applied. However, GH in blood samples is made up of diverse isoforms and isomers, of which the 22 and $20 \mathrm{kDa}$ forms are the most common. Furthermore, GH binding proteins can bind up to $50 \%$ of GH in the blood, which can interfere with the immunoassay of GH. Moreover, institutions measure GH in different ways. This variation in GH measurement underscores the importance of using the GH calibration standard 98 of 574 of the National Institute for Biological Standards and Control and using highly purified recombinant pituitary GH [24]. All manufacturers of measurement equipment should specify the validity of the assays, the GH isoforms measured, the analytes, the antibodies used, and whether GH binding proteins interfere with the measurements.

1.3. GH deficiency cannot be ruled out even if IGF-1 levels are normal. However, low serum IGF-1 levels may be indicative of GH deficiency in individuals who do not have a history of poorly controlled diabetes, chronic liver disease, or treatment with oral contraceptives.

1.4. GH deficiency can be diagnosed without GH stimulation testing when the typical clinical characteristics of GH deficiency are present, accompanied by deficiencies in three or more pituitary hormones with low serum IGF-1 levels.

GH deficiency cannot be ruled out even when serum IGF-1 levels are normal [13,25-27]. Higher BMIs are associated with a weaker GH response and increased IGF-1 levels [28]. However, if a patient with a high BMI has a low IGF-1 level, it can be considered as GH deficiency.

GH stimulation tests can be omitted if there are abnormally low levels of three or more pituitary hormones and IGF-1 levels are low (at least 2.0 standard deviations lower than normal), if the patient has a structural hypothalamic-pituitary condition, if the patient has a genetic condition that impacts the hypothalamic-pituitary axis, and if there is a structural lesion in the hypothalamus or pituitary gland $[1,25,29]$.

\subsection{Repeated GH stimulation testing should be per- formed in patients with childhood-onset GH deficiency if they do not have a proven genetic cause of GH defi- ciency or irreversible damage.}

1.6. Adult patients with irreversible pituitary damage should not regularly receive repeated GH stimulation tests.

When patients with idiopathic child-onset GH deficiency are re-evaluated in adulthood, most show normal GH secretion [30]. 
However, GH deficiency due to structural conditions, including tumors, surgery, radiation, and genetic disorders, do not improve in adulthood, so GH stimulation tests is not needed to be repeated in such patients [31].

\section{Treatment of growth hormone deficiency in adults}

\subsection{Unless contraindicated, GH therapy is recommended for patients with GH deficiency. GH therapy should start from a low dose, considering the patient's age, sex, and estrogen levels.}

2.2. Clinical improvements, side effects, and targeting serum IGF-1 levels within the age-adjusted reference range should be considered when adjusting the $\mathrm{GH}$ dose.

Unless contraindicated, GH replacement therapy is recommended for patients with $\mathrm{GH}$ deficiency diagnosed through $\mathrm{GH}$ stimulation tests. Patients should be started on low doses, since side effects are dose-dependent [32]. Common side effects include fluid retention, arthralgia, muscle pain, sensory disturbances, carpal tunnel syndrome, sleep apnea, sleep disorders, and dyspnea. Most of these side effects occur in around $20 \%$ of patients, in a dose-dependent manner. Side effects are more frequent in elderly, obese, and female patients, but subside after the dose is lowered [33]. The GH doses for adults were initially extrapolated based on body weight from dose recommendations for children. However, shifting from weight-based to individualized dose recommendations reduces side effects by half [34].

$\mathrm{GH}$ secretion decreases with age, and the side effects of GH are more common in elderly patients. Therefore, the appropriate therapeutic levels of GH are lower in elderly individuals and higher in younger individuals [35]. For individuals between the ages of 30 to 60 , a suitable starting dose is 0.2 to $0.3 \mathrm{mg} /$ day ( 0.8 to $1.2 \mathrm{IU} /$ day). For those below the age of 30 , a higher dose of 0.4 to $0.5 \mathrm{mg}$ /day ( 1.6 to $2.0 \mathrm{IU} /$ day) is possible, while in individuals above the age of 60 , the starting dose should be 0.1 to $0.2 \mathrm{mg} /$ day (0.4 to $0.8 \mathrm{IU} /$ day) and increased slowly thereafter (Fig. 1). The dosage should be increased by 0.1 to $0.2 \mathrm{mg} /$ day ( 0.4 to $0.8 \mathrm{IU} /$ day) monthly or bimonthly, and the maintenance level should be determined based on an evaluation of the patient's clinical response, side effects, and the normal range of IGF-1 levels for the patient's age group [1]. Although a normal IGF-1 level is targeted, the evidence remains unclear. Clinical responses can usually be observed after 6 months of treatment.

Females generally show higher GH resistance, and therefore require higher starting and maintenance doses [36]. Estrogen stimulates suppressor of cytokine signaling 2 (SOCS2), a specific non-competitive suppressor of $\mathrm{GH}$ in the liver [37], where $85 \%$ of serum IGF-1 originates. Since oral estrogen suppresses IGF-1, a higher dose of GH is required to maintain the same IGF-1 levels in females [37]. Even at the same IGF-1 levels, $\mathrm{GH}$ has less effect on body fat, low-density lipoprotein cholesterol, and bone turnover markers in females [38]. When oral estrogen is changed to transdermal estrogen, $\mathrm{GH}$ requirement is reduced [39].

\subsection{During the adjustment period, IGF-1 levels should} be monitored monthly or bimonthly. Once the maintenance level is determined, IGF-1 levels should be monitored around twice per year. monitoring should include an evaluation of the patient's clinical response, side effects, and IGF-1 levels.

During the adjustment period, Adequacy of GH dose including an evaluation of the patient's clinical response, side effects, and IGF-I levels [1] should be monitored monthly or bimonthly. Once the maintenance level is determined, IGF-1 levels should be monitored every six months (Fig. 1). The blood levels of lipid and fasting glucose should be tested every year, and if the initial bone mineral density is abnormal, bone mineral density should be re-evaluated every 1.5 to 2 years. Additionally, waist circumference and quality of life should be evaluated. If the patient is already taking thyroid or adrenal hormones, their doses should be adjusted after GH is introduced. These recommendations are based on empirical experience. Although it is unclear precisely how long GH should be administered, if there is no clear response to GH replacement after at least 1 year, treatment can be suspended [1].

The recently developed long-acting $\mathrm{GH}$ is formulated to be taken once a week or once a month instead of daily. Long-acting GH may be more effective because it reduces the inconvenience and discomfort of daily GH injections, thereby increasing compliance. A recently published meta-analysis reported long-acting $\mathrm{GH}$ and daily $\mathrm{GH}$ to have similar efficacy and safety profiles [40]. However, IGF-1 levels were significantly elevated in children with GH deficiency who received long-acting GH. Thus, additional research on long-acting $\mathrm{GH}$ should investigate how the peak and trough levels of GH and IGF-1 influence efficacy and safety, how the dose should be adjusted, when IGF-1 levels should be monitored, and how to compare long-term cost-effectiveness between daily and long-acting GH preparations [41]. 


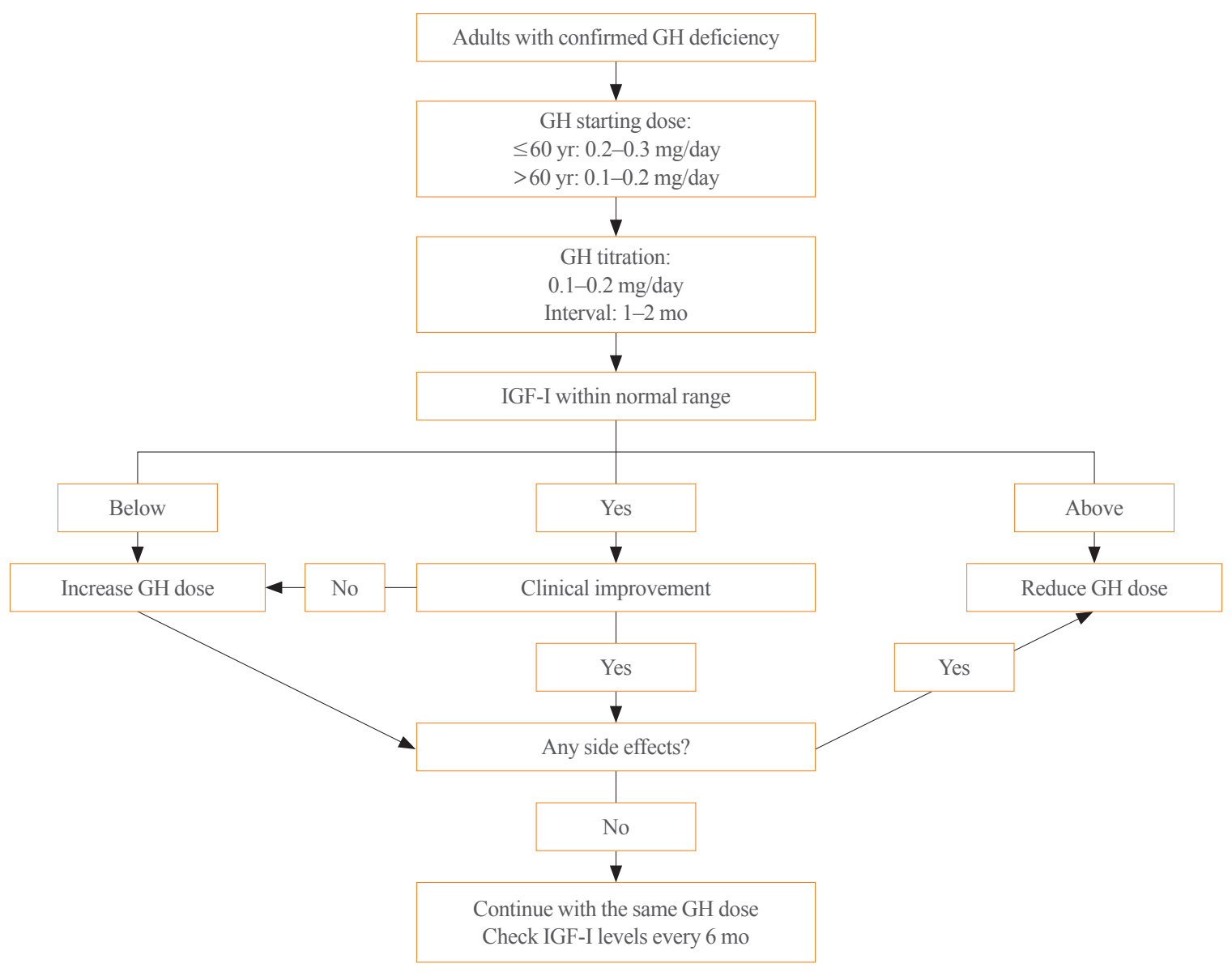

Fig. 1. Algorithm for growth hormone (GH) therapy in GH deficiency adults. IGF-1, insulin-like growth factor-1.

\section{Diagnosis and treatment of growth hormone deficiency in children and adolescents}

\subsection{Two or more GH stimulation tests should be admin- istered when GH deficiency is suspected in children.}

Childhood onset GH deficiency may be a long lasting endocrine conditions, starting in childhood and continuing into adulthood. Diagnostic workup of childhood onset GH deficiency include auxology, bone age view, measurement of IGF-1 and IGF binding protein 3, GH stimulation tests, brain imaging and, genetic tests if needed [42]. GH stimulation test is one of the most important diagnostic tools, but it is also intrusive and is accompanied by a risk of side effects [43]. The validity and reproducibility of GH stimulation tests have also been called into question $[44,45]$. Therefore, to diagnose GH deficiency, two or more $\mathrm{GH}$ stimulation tests should be administered. Children diagnosed with $\mathrm{GH}$ deficiency should receive $\mathrm{GH}$ replacement six to seven times a week, at 22 to $35 \mu \mathrm{g} / \mathrm{kg} /$ day (0.16 to $0.24 \mathrm{mg}$ / $\mathrm{kg} /$ week) or $12 \mathrm{IU}(4 \mathrm{mg})$ per body surface area $\left(\mathrm{m}^{2}\right) /$ week by subcutaneous injection until their epiphyseal plates close [46].

\subsection{Repeated GH stimulation tests are not required in GH patients with pituitary lesions or a proven genetic cause of GH deficiency.}

Controversy exists regarding the management in the transition period of adolescence of children or adolescents with $\mathrm{GH}$ deficiency. If a patient requires ongoing GH therapy, GH stimulation tests should be re-administered to reevaluate the function of the hypothalamic-pituitary axis. However, in patients with a high probability of irreversible GH deficiency, re-evaluation of GH status is not necessary [25]. Patients with structural lesions in the hypothalamus or pituitary gland or other structural problems, such as tumors, have a high risk of persistent GH deficiency $[47,48]$. Several genetic defects may also lead to an irreversible GH deficiency [49]. Therefore, GH stimulation tests is not need to be repeated in patients with definite genetic or struc- 
tural pituitary abnormalities.

\subsection{GH replacement should be continued in children and adolescents until the epiphyseal plates close or their full height is reached.}

The benefits of $\mathrm{GH}$ replacement during the transition period of adolescence are widely recognized. Childhood-onset GH deficiency contributes to low bone mass and an increased risk of fracture in adulthood [50]. It also results in developmental bone mass deficits both at the time of diagnosis and final height [51]. In a previous study, when GH replacement was resumed, body composition improved, with a $14 \%$ increase in muscle mass and a $7 \%$ decrease in body fat over a 2 -year period [35]. Some studies have reported deterioration in dyslipidemia after suspension of GH replacement in patients with childhood-onset GH deficiency [52]. Other studies have reported a reduction in cardiac dimensions after suspension of GH therapy during this transition period [53]. Therefore, GH replacement should be maintained until either the epiphyseal plates close or the final height is reached, since there are various benefits besides height gain.

\subsection{GH replacement should be resumed as soon as possi- ble in patients with $\mathrm{GH}$ deficiency during adolescence.}

It is widely known that appropriate GH replacement during the transition period of adolescence is necessary [54]. The purpose of GH replacement during this transition period is to maintain the continuity of hormonal care and to prevent health problems. Several studies have reported a risk of dropout among patients with GH deficiency who did not receive GH replacement during this transition period [54]. In one study, $21 \%$ of patients in puberty discontinued GH treatment without a comprehensive evaluation, and among those patients, $18 \%$ were lost to followup [55]. Thus, strategies for successful transition including standardized referral systems should be established [56]. If GH replacement is discontinued in such patients, it should be resumed as soon as possible.

\section{Benefits of growth hormone treatment}

\subsection{GH treatment improves body composition, exercise capacity, and bone mineral density in patients with GH deficiency.}

GH deficiency can cause decreased bone mineral density, muscle strength, and exercise capacity, deterioration in memory, decreased physical activity and vitality, lethargy, difficulty in concentration, and sleep disorders [57,58]. Patients also are exposed to a high risk of cardiovascular disease due to central obesity, dyslipidemia, or insulin resistance [59-61].

Several studies consistently reported that GH treatment had the significant effect on body composition including decrease in fat mass and increase in muscle mass $[62,63]$. It was further reported that $\mathrm{GH}$ replacement led to a decrease preferentially in visceral fat [64] and an increase in lean body mass [27,65], and improvements in muscle function [65] and lipid metabolism [66] can be expected as well. Studies in South Korea confirmed the tendency for GH treatment to achieve reductions in weight, body fat, and insulin resistance [67-70].

Published data have shown that bone mineral density in adults with GH deficiency is lower than the age- and sex-matched healthy controls [71-73]. Moreover, the severity of bone loss is correlated to the severity of GH deficiency [74]. Accordingly, the fracture risk in GH deficiency patients is 2- to 5-fold higher than in healthy controls $[75,76]$. Significant improvements in bone mineral density in response to GH treatment were reported among males and patients with severe bone loss [77]. Even in patients without a history of osteoporosis, GH treatment prevented fractures [78].

\subsection{GH treatment lowers the risk of cardiovascular disease in patients with GH deficiency, but there is insufficient evidence regarding its effects on mortality reduction.}

Previous studies have shown that GH deficiency increases the risk of cardiovascular disease via its negative effects on metabolic parameters, such as abdominal obesity, insulin resistance, and deterioration of lipid panels, and increases in various inflammatory markers [79]. GH deficiency has also been reported to negatively influence heart function and atherosclerosis by causing reduced thickness of the left ventricle, impairment of ejection fraction, and diastolic filling in the left ventricle [80]. A previous study reported that the cardiovascular mortality rate was twice as high in adult patients with GH deficiency than in their counterparts without GH deficiency [81]. Svensson et al. [82] reported that in patients with hypopituitarism, GH replacement led to lower rates of fatal myocardial infarction and a lower mortality rate [83]. A meta-analysis also found that GH replacement reduced the mortality rate among male patients with hypopituitarism [84], and a domestic study reported a reduction in markers of inflammation through $\mathrm{GH}$ replacement [70]. GH 
replacement can be expected to have a positive effect on cardiovascular disease. However, the mortality improvement is lower for women than for men [80], and the question of whether GH replacement can fully restore the long-term negative effects of GH deficiency on cardiovascular risk factors remains [83]. Therefore, it is still difficult to draw a definite conclusion on GH replacement and improvements in cardiovascular mortality, and additional longitudinal, large-scale research is required [85].

\subsection{GH treatment improves quality of life in patients with GH deficiency.}

Patients with GH deficiency may experience an impaired quality of life due to the deterioration in metabolic parameters and physical capacity, as well as because of their increased cardiovascular risk. Studies measuring the quality of life among adult patients diagnosed with GH deficiency using various tools in comparison to that of healthy adults found significantly poorer results for sleep, social integration, and physical activity among patients with GH deficiency, and their physical health negatively influenced their occupational status and daily life [86]. It was found by Svensson et al. [82] that GH replacement improved quality of life, and a domestic study also reported improvements in quality of life through increase of bone mineral density, lean body mass, and muscular strength, and decrease of body fat among healthy Korean women aged 60 or above after 6 months of GH replacement [87,88].

\section{Risks and side effects of growth hormone treatment}

The most common side effects of GH treatment are peripheral edema, joint pain, carpal tunnel syndrome, sensory disturbances, and increased blood glucose levels [33,89]. Side effects are more prevalent in elderly or obese patients and those who have been overtreated with GH [33]. The side effects of GH treatment can last for 3 or more years [90]. In particular, the possibility that GH replacement may cause malignant conditions to worsen should be carefully considered in the management of hypopituitarism.

\subsection{GH treatment is contraindicated in patients with an active malignancy (other than basal cell or squamous cell skin cancers).}

Theoretically, the increased activity of the IGF-1 axis resulting from GH treatment can exacerbate malignant tumors, as GH and increased IGF-1 levels are independently associated with the development of various malignant tumors [91]. Therefore, GH treatment is contraindicated in patients with malignancies. This recommendation is based on the theoretical possibility that GH treatment could increase the size of existing tumors, but there is not yet any concrete support for this proposal from clinical research [92]. Inpatients with GH deficiency, research on the risk of GH treatment-related recurrence of malignant tumors or secondary tumor formation has mostly been conducted among childhood cancer patients who had received GH treatment [9395]. Although some studies reported a slight increase in the risk of secondary tumor formation among childhood cancer patients who had previously received GH treatment $[94,95]$, most studies found no association between GH treatment and the recurrence of malignant tumors or secondary tumor formation [96103]. These results indicate that if an intracranial residual benign tumor is stable over a long period, there is no need to prohibit GH treatment. GH treatment can be administered to patients with a history of malignancy if they have been in remission for at least 1 year without recurrence [104].

\subsection{Changes in blood glucose levels should be observed during the course of GH treatment in patients with di- abetes mellitus, who may require their antidiabetic medication to be adjusted.}

GH and IGF-1 independently influence insulin resistance and insulin secretion by pancreatic $\beta$-cells [105]. Both increased and decreased GH and IGF-1 levels can cause abnormalities in blood glucose levels. The elevated blood glucose levels present in patients with acromegaly and the increased insulin resistance in patients with GH deficiency are clinically observed. Largescale clinical studies have reported GH treatment is related to insulin resistance and type 2 diabetes [106]. Insulin sensitivity following GH treatment varies since abnormlities in blood glucose levels depend on body composition, age, and genetic characteristics. According to a randomized controlled trial conducted by Hoffman et al. [27], compared to the placebo group, the group that received GH treatment had a statistically significant $13 \%$ increase in prediabetes and a $4 \%$ increase in diabetes. Therefore, when GH treatment is given, careful follow-up on diabetes is necessary, and adjustments to anti-diabetic medication should be considered.

5.3. Thyroid and adrenal gland function should be monitored during $\mathbf{G H}$ treatment in patients with hypopituitarism. 
It is common for patients with GH deficiency to have other manifestations of hypopituitarism, and thyroid and adrenal gland function - even if they are initially normal — should be monitored during GH treatment [58]. Hypothyroidism is accompanied by reduced secretion of IGF-1 and GH $[107,108]$. Therefore, in order to evaluate GH function accurately, central hypothyroidism should be treated first. During treatment, thyroid function must be evaluated, since $\mathrm{GH}$ treatment can reduce free thyroxine levels. Among patients with GH deficiency, 36\% to $47 \%$ of those with normal thyroid function became hypothyroid and $16 \%$ to $18 \%$ of those with hypothyroidism required an increase in levothyroxine dose within 3 to 6 months of GH treatment $[109,110]$. When GH treatment is started or the dose is changed, central hypothyroidism should be checked after 6 weeks [111].

In addition, hypothalamic-pituitary-adrenal function should be evaluated before and after GH treatment. Since GH suppresses the enzyme $11 \beta$-hydroxysteroid dehydrogenase type 1 converting cortisone to cortisol, the ratio of cortisone to cortisol is higher in patients with GH deficiency [108,112]. Therefore, even if adrenal insufficiency is present, it might not be diagnosed if accompanied by GH deficiency. When GH is given to such patients, possible adrenal function deterioration should be carefully considered [113,114].

\section{CONCLUSIONS}

Although it remains controversial whether GH treatment reduces cardiovascular mortality in patients with hypopituitarism, GH treatment in patients with GH deficiency has more benefits than harm. It is important to accurately diagnose GH deficiency through GH stimulation tests before starting GH treatment. The $\mathrm{GH}$ dose should be individualized to minimize side effects and to maximize clinical efficacy. Side effects and clinical response should be monitored regularly while patients are treated with the maintenance dose.

\section{CONFLICTS OF INTEREST}

No potential conflict of interest relevant to this article was reported.

\section{ACKNOWLEDGMENTS}

This work was supported by the Korean Endocrine Society.

\section{AUTHOR CONTRIBUTIONS}

Conception or design: J.H.K., H.W.C., S.O.C., C.R.K., C.H.K., E.J.L. Acquisition, analysis, or interpretation of data: J.H.K., H.W.C., S.O.C., C.R.K., C.H.K., E.J.L. Drafting the work or revising: J.H.K., H.W.C., S.O.C., C.R.K., K.H.P., D.J.L., K.J.K., J.S.L., G.K., Y.M.C., S.H.A., M.J.J., Y.H., J.H.L., B.K.K., Y. J.C., K.A.L., S.S.M., H.Y.A., H.S.C., S.M.H., D.Y.S., J.A.S., S.H.K., S.O., S.H.Y., B.J.K., C.H.S., S.W.K., C.H.K., E.J.L. Final approval of the manuscript: J.H.K., H.W.C., S.O.C., C.R.K., C.H.K., E.J.L.

\section{ORCID}

Jung Hee Kim https://orcid.org/0000-0003-1932-0234

Chong Hwa Kim https://orcid.org/0000-0002-4563-7772

Eun Jig Lee https://orcid.org/0000-0002-9876-8370

\section{REFERENCES}

1. Molitch ME, Clemmons DR, Malozowski S, Merriam GR, Vance ML; Endocrine Society. Evaluation and treatment of adult growth hormone deficiency: an Endocrine Society clinical practice guideline. J Clin Endocrinol Metab 2011; 96:1587-609.

2. Melmed S. Pathogenesis and diagnosis of growth hormone deficiency in adults. N Engl J Med 2019;380:2551-62.

3. Molitch ME. Nonfunctioning pituitary tumors and pituitary incidentalomas. Endocrinol Metab Clin North Am 2008;37: 151-71.

4. Arafah BM, Prunty D, Ybarra J, Hlavin ML, Selman WR. The dominant role of increased intrasellar pressure in the pathogenesis of hypopituitarism, hyperprolactinemia, and headaches in patients with pituitary adenomas. J Clin Endocrinol Metab 2000;85:1789-93.

5. Webb SM, Rigla M, Wagner A, Oliver B, Bartumeus F. Recovery of hypopituitarism after neurosurgical treatment of pituitary adenomas. J Clin Endocrinol Metab 1999;84:3696700 .

6. Mulder RL, Kremer LC, van Santen HM, Ket JL, van Trotsenburg AS, Koning CC, et al. Prevalence and risk factors of radiation-induced growth hormone deficiency in childhood cancer survivors: a systematic review. Cancer Treat Rev 2009;35:616-32.

7. Gleeson HK, Gattamaneni HR, Smethurst L, Brennan BM, Shalet SM. Reassessment of growth hormone status is re- 
quired at final height in children treated with growth hormone replacement after radiation therapy. J Clin Endocrinol Metab 2004;89:662-6.

8. Agha A, Rogers B, Sherlock M, O'Kelly P, Tormey W, Phillips J, et al. Anterior pituitary dysfunction in survivors of traumatic brain injury. J Clin Endocrinol Metab 2004;89:492936.

9. Schneider HJ, Kreitschmann-Andermahr I, Ghigo E, Stalla GK, Agha A. Hypothalamopituitary dysfunction following traumatic brain injury and aneurysmal subarachnoid hemorrhage: a systematic review. JAMA 2007;298:1429-38.

10. Hong JW, Kim JY, Kim YE, Lee EJ. Metabolic parameters and nonalcoholic fatty liver disease in hypopituitary men. Horm Metab Res 2011;43:48-54.

11. Yuen KC, Tritos NA, Samson SL, Hoffman AR, Katznelson L. American Association of Clinical Endocrinologists and American College of Endocrinology Disease State Clinical Review: update on growth hormone stimulation testing and proposed revised cut-point for the glucagon stimulation test in the diagnosis of adult growth hormone deficiency. Endocr Pract 2016;22:1235-44.

12. Aimaretti G, Corneli G, Razzore P, Bellone S, Baffoni C, Arvat E, et al. Comparison between insulin-induced hypoglycemia and growth hormone (GH)-releasing hormone+ arginine as provocative tests for the diagnosis of GH deficiency in adults. J Clin Endocrinol Metab 1998;83:1615-8.

13. Biller BM, Samuels MH, Zagar A, Cook DM, Arafah BM, Bonert V, et al. Sensitivity and specificity of six tests for the diagnosis of adult GH deficiency. J Clin Endocrinol Metab 2002;87:2067-79.

14. Corneli G, Di Somma C, Baldelli R, Rovere S, Gasco V, Croce CG, et al. The cut-off limits of the GH response to GH-releasing hormone-arginine test related to body mass index. Eur J Endocrinol 2005;153:257-64.

15. Colao A, Di Somma C, Savastano S, Rota F, Savanelli MC, Aimaretti G, et al. A reappraisal of diagnosing GH deficiency in adults: role of gender, age, waist circumference, and body mass index. J Clin Endocrinol Metab 2009;94:441422.

16. Qu XD, Gaw Gonzalo IT, Al Sayed MY, Cohan P, Christenson PD, Swerdloff RS, et al. Influence of body mass index and gender on growth hormone (GH) responses to GHreleasing hormone plus arginine and insulin tolerance tests. J Clin Endocrinol Metab 2005;90:1563-9.

17. Berg C, Meinel T, Lahner H, Yuece A, Mann K, Petersenn S. Diagnostic utility of the glucagon stimulation test in com- parison to the insulin tolerance test in patients following pituitary surgery. Eur J Endocrinol 2010;162:477-82.

18. Hamrahian AH, Yuen KC, Gordon MB, Pulaski-Liebert KJ, Bena J, Biller BM. Revised GH and cortisol cut-points for the glucagon stimulation test in the evaluation of GH and hypothalamic-pituitary-adrenal axes in adults: results from a prospective randomized multicenter study. Pituitary 2016; 19:332-41.

19. Gomez JM, Espadero RM, Escobar-Jimenez F, Hawkins F, Pico A, Herrera-Pombo JL, et al. Growth hormone release after glucagon as a reliable test of growth hormone assessment in adults. Clin Endocrinol (Oxf) 2002;56:329-34.

20. Conceicao FL, da Costa e Silva A, Leal Costa AJ, Vaisman M. Glucagon stimulation test for the diagnosis of GH deficiency in adults. J Endocrinol Invest 2003;26:1065-70.

21. Dichtel LE, Yuen KC, Bredella MA, Gerweck AV, Russell $\mathrm{BM}$, Riccio AD, et al. Overweight/obese adults with pituitary disorders require lower peak growth hormone cutoff values on glucagon stimulation testing to avoid overdiagnosis of growth hormone deficiency. J Clin Endocrinol Metab 2014;99:4712-9.

22. Wilson JR, Utz AL, Devin JK. Effects of gender, body weight, and blood glucose dynamics on the growth hormone response to the glucagon stimulation test in patients with pituitary disease. Growth Horm IGF Res 2016;26:24-31.

23. Garcia JM, Biller BMK, Korbonits M, Popovic V, Luger A, Strasburger CJ, et al. Macimorelin as a diagnostic test for adult GH deficiency. J Clin Endocrinol Metab 2018;103:3083-93.

24. Clemmons DR. Consensus statement on the standardization and evaluation of growth hormone and insulin-like growth factor assays. Clin Chem 2011;57:555-9.

25. Hartman ML, Crowe BJ, Biller BM, Ho KK, Clemmons $\mathrm{DR}$, Chipman JJ, et al. Which patients do not require a GH stimulation test for the diagnosis of adult GH deficiency? J Clin Endocrinol Metab 2002;87:477-85.

26. Hilding A, Hall K, Wivall-Helleryd IL, Saaf M, Melin AL, Thoren M. Serum levels of insulin-like growth factor I in 152 patients with growth hormone deficiency, aged 19-82 years, in relation to those in healthy subjects. J Clin Endocrinol Metab 1999;84:2013-9.

27. Hoffman AR, Kuntze JE, Baptista J, Baum HB, Baumann GP, Biller BM, et al. Growth hormone (GH) replacement therapy in adult-onset GH deficiency: effects on body composition in men and women in a double-blind, randomized, placebo-controlled trial. J Clin Endocrinol Metab 2004;89: 2048-56. 
28. Brabant G, Krogh Rasmussen A, Biller BM, Buchfelder M, Feldt-Rasmussen U, Forssmann K, et al. Clinical implications of residual growth hormone $(\mathrm{GH})$ response to provocative testing in adults with severe GH deficiency. J Clin Endocrinol Metab 2007;92:2604-9.

29. Yuen KCJ, Biller BMK, Radovick S, Carmichael JD, Jasim $\mathrm{S}$, Pantalone KM, et al. American Association of Clinical Endocrinologists and American College of Endocrinology guidelines for management of growth hormone deficiency in adults and patients transitioning from pediatric to adult care. Endocr Pract 2019;25:1191-232.

30. Wacharasindhu S, Cotterill AM, Camacho-Hubner C, Besser GM, Savage MO. Normal growth hormone secretion in growth hormone insufficient children retested after completion of linear growth. Clin Endocrinol (Oxf) 1996;45:553-6.

31. Nicolson A, Toogood AA, Rahim A, Shalet SM. The prevalence of severe growth hormone deficiency in adults who received growth hormone replacement in childhood [see comment]. Clin Endocrinol (Oxf) 1996;44:311-6.

32. Melmed S. Idiopathic adult growth hormone deficiency. J Clin Endocrinol Metab 2013;98:2187-97.

33. Holmes SJ, Shalet SM. Which adults develop side-effects of growth hormone replacement? Clin Endocrinol (Oxf) 1995;43:143-9.

34. Hoffman AR, Strasburger CJ, Zagar A, Blum WF, Kehely A, Hartman ML, et al. Efficacy and tolerability of an individualized dosing regimen for adult growth hormone replacement therapy in comparison with fixed body weight-based dosing. J Clin Endocrinol Metab 2004;89:3224-33.

35. Underwood LE, Attie KM, Baptista J; Genentech Collaborative Study Group. Growth hormone (GH) dose-response in young adults with childhood-onset GH deficiency: a two-year, multicenter, multiple-dose, placebo-controlled study. J Clin Endocrinol Metab 2003;88:5273-80.

36. Johannsson G, Bjarnason R, Bramnert M, Carlsson LM, Degerblad M, Manhem $\mathrm{P}$, et al. The individual responsiveness to growth hormone $(\mathrm{GH})$ treatment in GH-deficient adults is dependent on the level of GH-binding protein, body mass index, age, and gender. J Clin Endocrinol Metab 1996;81: 1575-81.

37. Birzniece V, Sata A, Ho KK. Growth hormone receptor modulators. Rev Endocr Metab Disord 2009;10:145-56.

38. Burman P, Johansson AG, Siegbahn A, Vessby B, Karlsson FA. Growth hormone (GH)-deficient men are more responsive to GH replacement therapy than women. J Clin Endocrinol Metab 1997;82:550-5.
39. Cook DM, Ludlam WH, Cook MB. Route of estrogen administration helps to determine growth hormone $(\mathrm{GH})$ replacement dose in GH-deficient adults. J Clin Endocrinol Metab 1999;84:3956-60.

40. Yang Y, Bai X, Yuan X, Zhang Y, Chen S, Yang H, et al. Efficacy and safety of long-acting growth hormone in children with short stature: a systematic review and meta-analysis. Endocrine 2019;65:25-34.

41. Miller BS, Velazquez E, Yuen KCJ. Long-acting growth hormone preparations: current status and future considerations. J Clin Endocrinol Metab 2020;105:dgz149.

42. Stanley T. Diagnosis of growth hormone deficiency in childhood. Curr Opin Endocrinol Diabetes Obes 2012;19:47-52.

43. Van Vught AJ, Nieuwenhuizen AG, Gerver WJ, Veldhorst MA, Brummer RJ, Westerterp-Plantenga MS. Pharmacological and physiological growth hormone stimulation tests to predict successful GH therapy in children. J Pediatr Endocrinol Metab 2009;22:679-94.

44. Ghigo E, Bellone J, Aimaretti G, Bellone S, Loche S, Cappa $\mathrm{M}$, et al. Reliability of provocative tests to assess growth hormone secretory status: study in 472 normally growing children. J Clin Endocrinol Metab 1996;81:3323-7.

45. Muller A, Scholz M, Blankenstein O, Binder G, Pfaffle R, Korner A, et al. Harmonization of growth hormone measurements with different immunoassays by data adjustment. Clin Chem Lab Med 2011;49:1135-42.

46. Grimberg A, DiVall SA, Polychronakos C, Allen DB, Cohen LE, Quintos JB, et al. Guidelines for growth hormone and insulin-like growth factor-I treatment in children and adolescents: growth hormone deficiency, idiopathic short stature, and primary insulin-like growth factor-I deficiency. Horm Res Paediatr 2016;86:361-97.

47. Kalina MA, Kalina-Faska B, Gruszczynska K, Baron J, Malecka-Tendera E. Usefulness of magnetic resonance findings of the hypothalamic-pituitary region in the management of short children with growth hormone deficiency: evidence from a longitudinal study. Childs Nerv Syst 2012;28:121-7.

48. Tillmann V, Tang VW, Price DA, Hughes DG, Wright NB, Clayton PE. Magnetic resonance imaging of the hypothalamic-pituitary axis in the diagnosis of growth hormone deficiency. J Pediatr Endocrinol Metab 2000;13:1577-83.

49. Mullis PE. Genetics of isolated growth hormone deficiency. J Clin Res Pediatr Endocrinol 2010;2:52-62.

50. Boot AM, van der Sluis IM, Krenning EP, de Muinck Keizer-Schrama SM. Bone mineral density and body composition in adolescents with childhood-onset growth hormone 
deficiency. Horm Res 2009;71:364-71.

51. Aimaretti G, Corneli G, Rovere S, Croce CG, Ghigo E, Procopio M. Is GH therapy useful to preserve bone mass in transition-phase patients with GH deficiency? J Endocrinol Invest 2005;28(10 Suppl):28-32.

52. Bechtold S, Bachmann S, Putzker S, Dalla Pozza R, Schwarz HP. Early changes in body composition after cessation of growth hormone therapy in childhood-onset growth hormone deficiency. J Clin Densitom 2011;14:471-7.

53. Colao A, di Somma C, Pivonello R, Cuocolo A, Spinelli L, Bonaduce $\mathrm{D}$, et al. The cardiovascular risk of adult GH deficiency (GHD) improved after GH replacement and worsened in untreated GHD: a 12-month prospective study. J Clin Endocrinol Metab 2002;87:1088-93.

54. Ahmid M, Ahmed SF, Shaikh MG. Childhood-onset growth hormone deficiency and the transition to adulthood: current perspective. Ther Clin Risk Manag 2018;14:2283-91.

55. Ahmid M, Fisher V, Graveling AJ, McGeoch S, McNeil E, Roach J, et al. An audit of the management of childhoodonset growth hormone deficiency during young adulthood in Scotland. Int J Pediatr Endocrinol 2016;2016:6.

56. Downing J, Gleeson HK, Clayton PE, Davis JR, Wales JK, Callery P. Transition in endocrinology: the challenge of maintaining continuity. Clin Endocrinol (Oxf) 2013;78:2935.

57. Roshan S, Nader S, Orlander P. Review: ageing and hormones. Eur J Clin Invest 1999;29:210-3.

58. Kim SY. Diagnosis and treatment of hypopituitarism. Endocrinol Metab (Seoul) 2015;30:443-55.

59. Weaver JU, Monson JP, Noonan K, John WG, Edwards A, Evans KA, et al. The effect of low dose recombinant human growth hormone replacement on regional fat distribution, insulin sensitivity, and cardiovascular risk factors in hypopituitary adults. J Clin Endocrinol Metab 1995;80:153-9.

60. Beshyah SA, Johnston DG. Cardiovascular disease and risk factors in adults with hypopituitarism. Clin Endocrinol (Oxf) 1999;50:1-15.

61. Khang AR, Ku EJ, Kim YA, Roh E, Bae JH, Oh TJ, et al. Sex differences in the prevalence of metabolic syndrome and its components in hypopituitary patients: comparison with an age- and sex-matched nationwide control group. Pituitary 2016;19:573-81.

62. Attanasio AF, Bates PC, Ho KK, Webb SM, Ross RJ, Strasburger $\mathrm{CJ}$, et al. Human growth hormone replacement in adult hypopituitary patients: long-term effects on body composition and lipid status: 3-year results from the HypoCCS
Database. J Clin Endocrinol Metab 2002;87:1600-6.

63. Attanasio AF, Shavrikova E, Blum WF, Cromer M, Child $\mathrm{CJ}$, Paskova M, et al. Continued growth hormone (GH) treatment after final height is necessary to complete somatic development in childhood-onset GH-deficient patients. J Clin Endocrinol Metab 2004;89:4857-62.

64. Beauregard C, Utz AL, Schaub AE, Nachtigall L, Biller $\mathrm{BM}$, Miller KK, et al. Growth hormone decreases visceral fat and improves cardiovascular risk markers in women with hypopituitarism: a randomized, placebo-controlled study. J Clin Endocrinol Metab 2008;93:2063-71.

65. Gotherstrom G, Elbornsson M, Stibrant-Sunnerhagen K, Bengtsson BA, Johannsson G, Svensson J. Ten years of growth hormone $(\mathrm{GH})$ replacement normalizes muscle strength in GH-deficient adults. J Clin Endocrinol Metab 2009;94:809-16.

66. Maison P, Griffin S, Nicoue-Beglah M, Haddad N, Balkau $\mathrm{B}$, Chanson P, et al. Impact of growth hormone (GH) treatment on cardiovascular risk factors in GH-deficient adults: a metaanalysis of blinded, randomized, placebo-controlled trials. J Clin Endocrinol Metab 2004;89:2192-9.

67. Kim KW, Nam SY, Kim DS, Ahn CW, Kim KR, Lim SK, et al. Effects of growth hormone treatment beyond the body fat changes in GH-deficient adults. Korean J Obes 2013;22:5665.

68. Choi HS, Kim SS, Ko KJ, Lee EJ, Park IW, Park TW, et al. The effects of growth hormone administration on the markers of cardiovascular disease in growth hormone deficient adults. Korean J Med 2005;68:519-27.

69. Park JK, Hong JW, Kim CO, Kim SW, Lim CY, Chung YS, et al. Sustained-release recombinant human growth hormone improves body composition and quality of life in adults with somatopause. J Am Geriatr Soc 2011;59:944-7.

70. Hong JW, Park JK, Lim CY, Kim SW, Chung YS, Kim SW, et al. A weekly administered sustained-release growth hormone reduces visceral fat and waist circumference in abdominal obesity. Horm Metab Res 2011;43:956-61.

71. Holmes SJ, Economou G, Whitehouse RW, Adams JE, Shalet SM. Reduced bone mineral density in patients with adult onset growth hormone deficiency. J Clin Endocrinol Metab 1994;78:669-74.

72. Murray RD, Columb B, Adams JE, Shalet SM. Low bone mass is an infrequent feature of the adult growth hormone deficiency syndrome in middle-age adults and the elderly. J Clin Endocrinol Metab 2004;89:1124-30.

73. Rosen T, Hansson T, Granhed H, Szucs J, Bengtsson BA. 
Reduced bone mineral content in adult patients with growth hormone deficiency. Acta Endocrinol (Copenh) 1993;129: 201-6.

74. Colao A, Di Somma C, Pivonello R, Loche S, Aimaretti G, Cerbone $\mathrm{G}$, et al. Bone loss is correlated to the severity of growth hormone deficiency in adult patients with hypopituitarism. J Clin Endocrinol Metab 1999;84:1919-24.

75. Vestergaard P, Jorgensen JO, Hagen C, Hoeck HC, Laurberg P, Rejnmark L, et al. Fracture risk is increased in patients with GH deficiency or untreated prolactinomas: a case-control study. Clin Endocrinol (Oxf) 2002;56:159-67.

76. Rosen T, Wilhelmsen L, Landin-Wilhelmsen K, Lappas G, Bengtsson BA. Increased fracture frequency in adult patients with hypopituitarism and GH deficiency. Eur J Endocrinol 1997; 137:240-5.

77. Gotherstrom G, Bengtsson BA, Bosaeus I, Johannsson G, Svensson J. Ten-year GH replacement increases bone mineral density in hypopituitary patients with adult onset GH deficiency. Eur J Endocrinol 2007;156:55-64.

78. Mo D, Fleseriu M, Qi R, Jia N, Child CJ, Bouillon R, et al. Fracture risk in adult patients treated with growth hormone replacement therapy for growth hormone deficiency: a prospective observational cohort study. Lancet Diabetes Endocrinol 2015;3:331-8.

79. Giovannini L, Tirabassi G, Muscogiuri G, Di Somma C, Colao A, Balercia G. Impact of adult growth hormone deficiency on metabolic profile and cardiovascular risk [review]. Endocr J 2015;62:1037-48.

80. Colao A, Cuocolo A, Di Somma C, Cerbone G, Della Morte AM, Nicolai E, et al. Impaired cardiac performance in elderly patients with growth hormone deficiency. J Clin Endocrinol Metab 1999;84:3950-5.

81. Rosen T, Bengtsson BA. Premature mortality due to cardiovascular disease in hypopituitarism. Lancet 1990;336:2858.

82. Svensson J, Mattsson A, Rosen T, Wiren L, Johannsson G, Bengtsson BA, et al. Three-years of growth hormone (GH) replacement therapy in GH-deficient adults: effects on quality of life, patient-reported outcomes and healthcare consumption. Growth Horm IGF Res 2004;14:207-15.

83. van Bunderen CC, van Nieuwpoort IC, Arwert LI, Heymans MW, Franken AA, Koppeschaar HP, et al. Does growth hormone replacement therapy reduce mortality in adults with growth hormone deficiency?: data from the Dutch National Registry of Growth Hormone Treatment in adults. J Clin Endocrinol Metab 2011;96:3151-9.
84. Pappachan JM, Raskauskiene D, Kutty VR, Clayton RN. Excess mortality associated with hypopituitarism in adults: a meta-analysis of observational studies. J Clin Endocrinol Metab 2015;100:1405-11.

85. Fleseriu M, Hashim IA, Karavitaki N, Melmed S, Murad $\mathrm{MH}$, Salvatori R, et al. Hormonal replacement in hypopituitarism in adults: an Endocrine Society Clinical Practice Guideline. J Clin Endocrinol Metab 2016;101:3888-921.

86. Bjork S, Jonsson B, Westphal O, Levin JE. Quality of life of adults with growth hormone deficiency: a controlled study. Acta Paediatr Scand Suppl 1989;356:55-60,73-4.

87. Woo JT, Kim DY, Kim SW, Yang IM, Kim JW, Kim YS, et al. Effects of human growth hormone treatment in healthy older female. J Korean Soc Endocrinol 1992;7:352-7.

88. Kim Y, Hong JW, Chung YS, Kim SW, Cho YW, Kim JH, et al. Efficacy and safety of sustained-release recombinant human growth hormone in Korean adults with growth hormone deficiency. Yonsei Med J 2014;55:1042-8.

89. Moller N, Jorgensen JO. Effects of growth hormone on glucose, lipid, and protein metabolism in human subjects. Endocr Rev 2009;30:152-77.

90. Chipman JJ, Attanasio AF, Birkett MA, Bates PC, Webb S, Lamberts SW. The safety profile of GH replacement therapy in adults. Clin Endocrinol (Oxf) 1997;46:473-81.

91. Boguszewski CL, Boguszewski MC. Growth hormone's links to cancer. Endocr Rev 2019;40:558-74.

92. Sheppard MC. Growth hormone therapy does not induce cancer. Nat Clin Pract Endocrinol Metab 2006;2:532-3.

93. Packer RJ, Boyett JM, Janss AJ, Stavrou T, Kun L, Wisoff J, et al. Growth hormone replacement therapy in children with medulloblastoma: use and effect on tumor control. J Clin Oncol 2001;19:480-7.

94. Sklar CA, Mertens AC, Mitby P, Occhiogrosso G, Qin J, Heller G, et al. Risk of disease recurrence and second neoplasms in survivors of childhood cancer treated with growth hormone: a report from the Childhood Cancer Survivor Study. J Clin Endocrinol Metab 2002;87:3136-41.

95. Ergun-Longmire B, Mertens AC, Mitby P, Qin J, Heller G, Shi W, et al. Growth hormone treatment and risk of second neoplasms in the childhood cancer survivor. J Clin Endocrinol Metab 2006;91:3494-8.

96. Arnold JR, Arnold DF, Marland A, Karavitaki N, Wass JA. GH replacement in patients with non-functioning pituitary adenoma (NFA) treated solely by surgery is not associated with increased risk of tumour recurrence. Clin Endocrinol (Oxf) 2009;70:435-8.

Copyright (C) 2020 Korean Endocrine Society 
97. Buchfelder M, Kann PH, Wuster C, Tuschy U, Saller B, Brabant $\mathrm{G}$, et al. Influence of GH substitution therapy in deficient adults on the recurrence rate of hormonally inactive pituitary adenomas: a case control study. Eur J Endocrinol 2007;157:149-56.

98. Chung TT, Drake WM, Evanson J, Walker D, Plowman PN, Chew SL, et al. Tumour surveillance imaging in patients with extrapituitary tumours receiving growth hormone replacement. Clin Endocrinol (Oxf) 2005;63:274-9.

99. Frajese G, Drake WM, Loureiro RA, Evanson J, Coyte D, Wood DF, et al. Hypothalamo-pituitary surveillance imaging in hypopituitary patients receiving long-term GH replacement therapy. J Clin Endocrinol Metab 2001;86:51725.

100. Hatrick AG, Boghalo P, Bingham JB, Ayres AB, Sonksen PH, Russell-Jones DL. Does GH replacement therapy in adult GH-deficient patients result in recurrence or increase in size of pituitary tumours? Eur J Endocrinol 2002;146: 807-11.

101. Jostel A, Mukherjee A, Hulse PA, Shalet SM. Adult growth hormone replacement therapy and neuroimaging surveillance in brain tumour survivors. Clin Endocrinol (Oxf) 2005;62:698-705.

102. Karavitaki N, Warner JT, Marland A, Shine B, Ryan F, Arnold J, et al. GH replacement does not increase the risk of recurrence in patients with craniopharyngioma. Clin Endocrinol (Oxf) 2006;64:556-60.

103. Olsson DS, Buchfelder M, Schlaffer S, Bengtsson BA, Jakobsson KE, Johannsson $\mathrm{G}$, et al. Comparing progression of non-functioning pituitary adenomas in hypopituitarism patients with and without long-term GH replacement therapy. Eur J Endocrinol 2009;161:663-9.

104. Sklar CA, Antal Z, Chemaitilly W, Cohen LE, Follin C, Meacham LR, et al. Hypothalamic-pituitary and growth disorders in survivors of childhood cancer: an Endocrine Society Clinical Practice Guideline. J Clin Endocrinol Metab 2018;103:2761-84.

105. Yuen KC, Dunger DB. Impact of treatment with recombinant human GH and IGF-I on visceral adipose tissue and glucose homeostasis in adults. Growth Horm IGF Res 2006;16 Suppl A:S55-61.

106. Al-Shoumer KA, Gray R, Anyaoku V, Hughes C, Beshyah $\mathrm{S}$, Richmond W, et al. Effects of four years' treatment with biosynthetic human growth hormone $(\mathrm{GH})$ on glucose homeostasis, insulin secretion and lipid metabolism in GHdeficient adults. Clin Endocrinol (Oxf) 1998;48:795-802.

107. Behan LA, Monson JP, Agha A. The interaction between growth hormone and the thyroid axis in hypopituitary patients. Clin Endocrinol (Oxf) 2011;74:281-8.

108. Filipsson H, Johannsson G. GH replacement in adults: interactions with other pituitary hormone deficiencies and replacement therapies. Eur J Endocrinol 2009;161 Suppl 1:S85-95.

109. Jorgensen JO, Moller J, Laursen T, Orskov H, Christiansen JS, Weeke J. Growth hormone administration stimulates energy expenditure and extrathyroidal conversion of thyroxine to triiodothyronine in a dose-dependent manner and suppresses circadian thyrotrophin levels: studies in GH-deficient adults. Clin Endocrinol (Oxf) 1994;41:609-14.

110. Agha A, Walker D, Perry L, Drake WM, Chew SL, Jenkins PJ, et al. Unmasking of central hypothyroidism following growth hormone replacement in adult hypopituitary patients. Clin Endocrinol (Oxf) 2007;66:72-7.

111. Losa M, Scavini M, Gatti E, Rossini A, Madaschi S, Formenti I, et al. Long-term effects of growth hormone replacement therapy on thyroid function in adults with growth hormone deficiency. Thyroid 2008;18:1249-54.

112. Mazziotti G, Giustina A. Glucocorticoids and the regulation of growth hormone secretion. Nat Rev Endocrinol 2013;9: 265-76.

113. Stewart PM, Toogood AA, Tomlinson JW. Growth hormone, insulin-like growth factor-I and the cortisol-cortisone shuttle. Horm Res 2001;56 Suppl 1:1-6.

114. Giavoli C, Libe R, Corbetta S, Ferrante E, Lania A, Arosio $\mathrm{M}$, et al. Effect of recombinant human growth hormone $(\mathrm{GH})$ replacement on the hypothalamic-pituitary-adrenal axis in adult GH-deficient patients. J Clin Endocrinol Metab 2004;89:5397-401. 